\title{
The Effect of Using the Fire-Brick Fragments as a Thermal Energy Storage Material on Thermal Efficiency of Solar Air Heater
}

\author{
Ahmet Süslü ${ }^{*}$, Recep Külcü ${ }^{2}$, Can Ertekin ${ }^{3}$ \\ ${ }^{1^{*}}$ Isparta University of Applied Sciences, Faculty of Agriculture, Department of Agricultural Machinery and Technologies Engineering, Isparta, Turkey, \\ (ORCID: 0000-0003-4016-589X), mail@ahmetsuslu.com \\ 2 Isparta University of Applied Sciences, Faculty of Agriculture, Department of Agricultural Machinery and Technologies Engineering, Isparta, Turkey, \\ (ORCID: 0000-0002-7185-6514), recepkulcu@isparta.edu.tr \\ ${ }^{3}$ Akdeniz University, Faculty of Agriculture, Department of Agricultural Machinery and Technologies Engineering, Antalya, Turkey, \\ (ORCID: 0000-0003-2987-2438), ertekin@akdeniz.edu.tr
}

(First received 21 September 2021 and in final form 6 December 2021)

(DOI: $10.31590 /$ ejosat.997956)

ATIF/REFERENCE: Süslü, A., Külcü, R., \& Ertekin, C. (2021). The Effect of Using the Fire-brick Fragments as a Thermal Energy Storage Material on Thermal Efficiency of Solar Air Heater. European Journal of Science and Technology, (31), 358-364.

\begin{abstract}
The hot air needed in applications such as drying agricultural products and space heating can be obtained with air-heated solar collectors. Air has a lower heat transfer coefficient than water. Using storage materials with increased surface area in air-heated solar collectors provides both obtaining higher temperatures output air and increased the total efficiency of the collector by storing energy. Refractory materials such as fire bricks have low thermal conductivity and high thermal capacities. In this study, the effects of refractory fire-brick fragments which are a kind of refractory in storage and reuse of thermal energy on collector efficiency were investigated. Fire brick fragments of different densities were applied into the solar air heater collector and their thermal efficiencies were compared during under radiation and cooling.
\end{abstract}

Keywords: Solar Air Heater, Thermal Energy Storage, Fire Brick Fragments.

\section{Ateş Tuğlası Parçalarının Güneş Enerjili Hava Isıtıcılarında Isıl Enerji Depolama Malzemesi Olarak Kullanılmasının Isıl Verimliliğine Etkisi}

$\ddot{O} \mathbf{z}$

Tarım ürünlerinin kurutulması ve mekân 1sıtması gibi uygulamalarda ihtiyaç duyulan sıcak hava, hava 1sıtıcılı güneş kollektörleri ile elde edilebilmektedir. Suya göre, havanın 1sı transfer katsayısı daha düşüktür. Bu sebeple hava 1sıtıcılı güneş kollektörlerinde yüzey alanı artırılmış depolama malzemeleri kullanılarak hem daha yüksek sıcaklıklarda hava elde edebilmekte hem de enerjinin depolanması sağlanarak kollektörün toplam verimi artırılabilmektedir. Ateş tuğlaları gibi yüksek sıcaklıklara dayanıklı malzemeler, düşük 1sı iletkenliğine ve yüksek 1sı kapasitelerine sahiptirler. Bu çalışmada, depolama ve ısıl enerjinin tekrar kullanımında bir tür refrakter olan ateş tuğlasına ait parçalar kollektör içerisine yerleştirilerek, kollektörün verimi üzerine etkileri incelenmiştir. Hava 1sıtıcılı güneş kollektörüne farklı miktarlarda ateş tuğlası parçaları uygulanmış, ışınım altında ve soğutma sırasında 1sıl verimleri karşılaştırılmıştır. Anahtar Kelimeler: Hava Isıtıcılı Güneş Kollektörü, Isıl Enerji Depolama, Ateş Tuğlası Parçaları.

*Corresponding Author: mail@ahmetsuslu.com 


\section{Introduction}

Mankind realized that using of solar energy is in his benefit ages ago. Greek historian Xenophon's 'Memoribilia' named work recorded that the Greek philosopher Socrates's (470 -399 BC) in order to have cool dwellings in summer and warm dwellings in winter, that the south-facing sides should be built higher [1, 2]. Solar thermal collectors used for different applications such as solar water heating, space heating and cooling, solar refrigeration, industrial process heat, solar desalination, solar thermal power and simultaneous electricity and heat generation [3]. Hot water solar collectors are most commonly used panel type in Turkey. In addition to hot water, solar air heaters have been developed in order to meet required hot air [4]. The use of solar air heater (SAH) has become widespread where dwellings heating, drying of agricultural products and medium and low temperatures are needed in many applications $[5,6,7]$. SAHs are used due to their rare maintenance and simple structure [8]. Solar air heaters can be classified as in Figure 1 [9]. While sensible heat based SAHs are suitable option for low temperature solar thermal systems, latent heat storage in phase change materials (PCMs) is also the most suitable solution for thermal energy storage due to their high latent heat. In addition, energy storage in SAHs is an effective design to yield a higher and more stable output compared to conventional SAHs $[10,11,12]$.

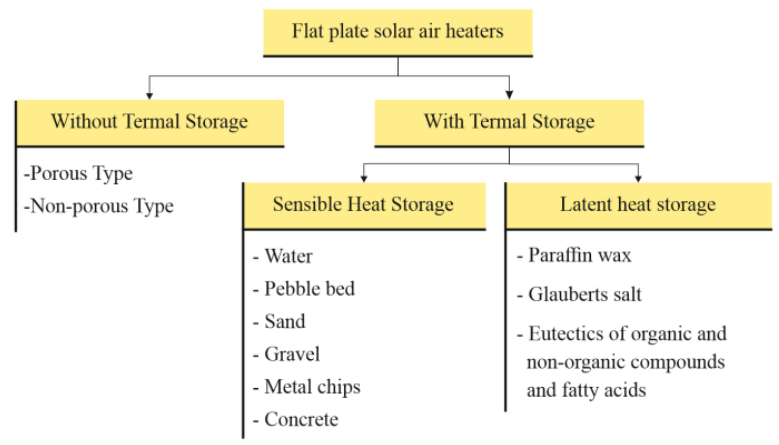

Figure 1. Classification of solar air heaters.

In Table 1, commonly used sensible and latent heat storage materials properties were given [9].

Table 1. Thermo-physical properties of different materials.

\begin{tabular}{|c|c|c|c|c|}
\hline $\begin{array}{c}\text { Thermal energy } \\
\text { storage }\end{array}$ & $\begin{array}{c}\text { Specifi } \\
\text { c heat } \\
\mathrm{kJ} / \mathrm{kg} . \mathrm{K}\end{array}$ & $\begin{array}{c}\text { Thermal } \\
\text { conductivity } \\
W / m . K\end{array}$ & $\begin{array}{c}\text { Density } \\
\mathrm{kg} / \mathrm{m}^{3}\end{array}$ & $\begin{array}{c}\text { Latent heat } \\
\text { of fusion } \\
\mathrm{kJ} / \mathrm{kg}\end{array}$ \\
\hline Rockbed & 1 & 3,26 & 2240 & - \\
\hline Brick & 790 & 0,90 & 1920 & - \\
\hline Concrete & 840 & 0,79 & 1600 & - \\
\hline Pebble bed & 0,8 & 2,9 & 1430 & - \\
\hline Paraffin wax & $2,1-8,4$ & 0,24 & $920-795$ & 189 \\
\hline Hytherm oil & 0,73 & 0,97 & 725 & - \\
\hline Glauber's salt & 2,5 & 2,25 & $1330-1460$ & 251 \\
\hline Organic PCM & 2 & - & 800 & 190 \\
\hline Inorganic PCM & 2 & - & 1600 & 230 \\
\hline Granular carbon & 0,93 & 0,11 & 460 & - \\
\hline Water & 4178 & 0,612 & 998 & 334 \\
\hline Al composites & 0,89 & 0,21 & 2707 & - \\
\hline Iron gravels & 0,56 & 37 & 7200 & - \\
\hline
\end{tabular}

The storage of solar energy is important for the future success of solar energy use. In cases where the energy needs to be continuity, such as drying of agricultural products or space heating, the energy must be stored temporarily. The storable energy amount varies depends on the properties of the PCMs and e-ISSN: 2148-2683 sensible or thermochemical materials used in the storage of heat energy $[13,14,15]$. The storage of thermal energy has been used for a long time. There are plants that produce electricity from concentrating solar power, for the generation of electricity needed when solar radiation cannot reach the earth [16, 17]. Although SAH applications are highly efficient, the heat transfer between the absorber surface and the fluidized air is low. With this motivation many researchers have studied to increase the thermal efficiency of SAHs by increasing the convective area with artificial roughness and barrier fins of different geometries. Nowadays, the studies on the subject have increased in bringing together designs that have enhanced storage and heat conduction $[18,19,20,21]$. Generally, the choice of material to store energy is related to the end use scope and method of using the energy. An energy storage system be able to evaluate in terms of capacity, charge and discharge time, reusability, efficiency and cost. However, a solar air heater can be designed using less material, even using some non-commercial value scrap [7, 15].

Saravanakumar and Mayilsamy, studied the mixed thermal storage material and found that the gravel with iron scraps gives better \%10-20 efficiency than other storage materials [22]. Natarajan et al., presented experimental results of a tunnel type agricultural product dryer so as to thermal storage materials effects on thermal efficiency. According to their experimental results, without thermal storage, sand bed, rock bed and aluminum conditions were found $9.9 \%, 15.46 \%, 14.75 \%$ and $13.7 \%$, respectively [23]. Singh et al., compared thermal efficiency of a solar air heater collector with various combinations of thermal storage media. They observed the best heat storage capability have coupled with aluminum cans and sand as compared to other systems. They achieved maximum efficiency (44.45\%) with SAH with aluminum cans and sand [24].

Fire bricks are light, porous refractories and contain $60-70 \%$ silica (Silicon Dioxide) and 30-40\% alumina (Aluminum Oxide). Materials other than these two components in a good fire brick should not exceed 5\%. It has low thermal conductivity and high heat storage capacity [25]. For this reason, although researchers studying on energy storage and recovery systems with fire bricks today, but it is not enough to turn into a commercial product.

The storable energy is directly related to the solar radiation duration, solar angles, cloudiness rate, and the amount of storage material. It is expected that the experimental conditions do not vary as much as possible because the variation of the angle and amount of solar radiation on different days or hours may result in errors in the production of correct data by monitoring the effects of the application factors tested. Panel efficiencies determination experiments are generally carries out indoors because efficiency may effects than outdoor conditions due to the amount of radiation can't keep constant and the air flows may cause heat losses on the surface are prevented. The use of solar simulators to conduct efficiency testing of solar panels is common due to repeatable, adjustable and stabilizable [26-27].

In this study, the effects of using fire brick fragments in the panel on collector efficiency were investigated. In this context, fire brick fragments as filling material were placed in the collector with 4 different densities $\left(3,7,11,13 \mathrm{~kg} \cdot \mathrm{m}^{-2}\right)$, control (without storage material) experiments were performed by using solar simulator. 


\section{Material}

\subsection{Solar Simulator}

Solar simulators are used in indoor testing of equipment that converts solar energy into different energy types such as photovoltaic cells and solar collectors under controlled and repeatable conditions. The simulators are uses electrically powered halogen lamps which provide the equivalent light spectrum of daylight. It is easy to recognize the absolute effects of a change in a given factor on panel efficiency in panels tested with the simulator. In addition, climatic changes eliminate the uncertainty caused by uncontrolled outdoor factors such as cloudiness factor or wind. The fundamental of the solar simulator is that it matches the spectrum of daylight and that the radiation is homogeneously distributed across the panel surface to be tested $[28,29]$. Experiments were conducted with a solar simulator consisting of 30 halogen lamps $(330 \mathrm{~W})$ in $6 \times 5$ matrix. The radiation intensity of each lamp can be adjusted by the dimmer switch to which it is connected. The homogeneity of the radiation reaching the surface can be adjusted in this way. The simulator can generate radiation for any value between $0-1350 \mathrm{~W} \cdot \mathrm{m}^{\wedge}(-2)$ Fig [2]. For the experiments to be performed under $1000 \mathrm{~W} \cdot \mathrm{m}^{\wedge}(-$ 2 ), the radiation measurements made with DeltaOhm brand HD2102.2 model radiometer from 35 points on the panel were adjusted to be homogeneous.

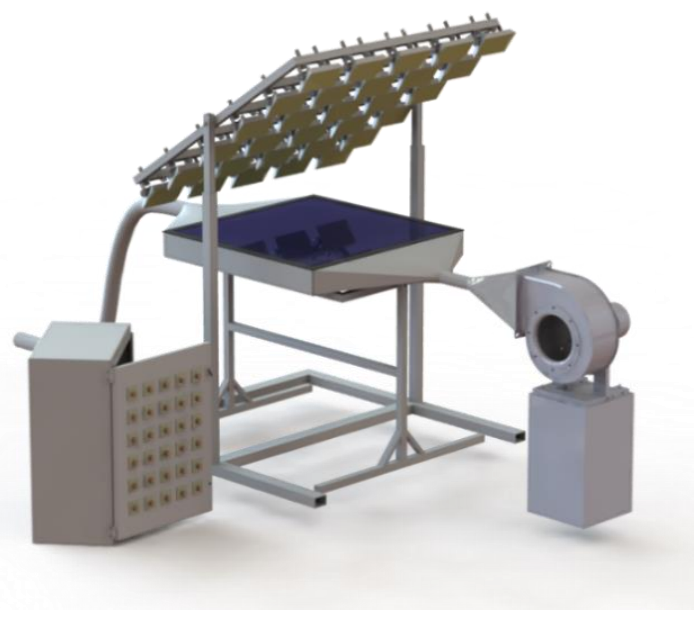

Figure 2. Solar simulator

\subsection{Automation and Logging System}

PLC based automation system has been developed for the control of variables such as application of radiation during constant time, cooling time and air speed, and saving of temperature values to an external memory periodically. Temperature values were measured with thermal pairs at 4 different points including input, output, ambient and in-panel. The frequency value of the radial fan operating with alternating current and that provides air supply can be adjusted via automation. The frequency driver was used to conduct experiments which the outlet air velocity was equal of a specified value via frequency. The outlet air velocity measures with HK Instruments AVT-D model anemometer. Delta branded MPU is programmed for automatic control. In addition, an interface designed for the input parameters by user Figure 3.

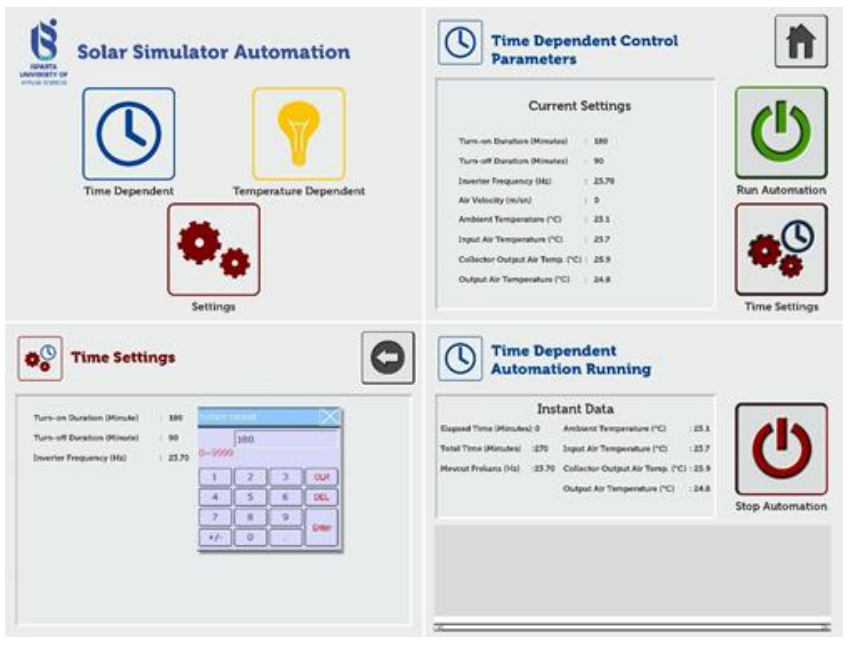

Figure 3. Pages of automation interface

\subsection{Collector and Thermal Energy Storage Material}

On the experiments, a solar collector with standard air heating with glass on the top, matt black on the absorber and without roughness was used. The inner volume of the collector can be filled with different materials and the top surface has a hinged shutter design. The absorber surface area of the panel (1.02 $\mathrm{m} \times 0.72 \mathrm{~m})$ is $0.74 \mathrm{~m}^{2}$ and the input-output air channels are converted to circular. Fire brick fragments were used as thermal storage material with approximately $0.974 \mathrm{~kg} \cdot \mathrm{dm}^{-3}(\mathrm{w} / \mathrm{v})$ Figure 4.

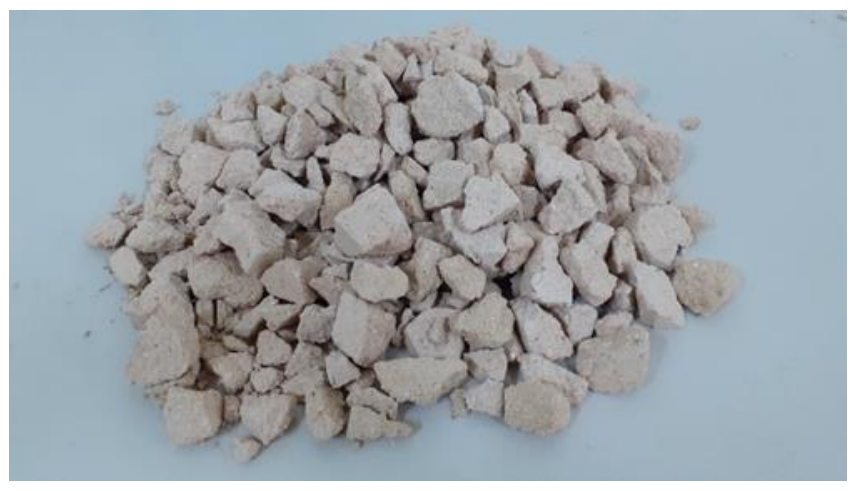

Figure 4. To used cracked fire bricks as thermal energy storage.

\section{Method}

In the experiments, the effects of the application of fire brick fragments into the collector at different densities on the thermal efficiency of the collector were observed. The densities were applied to 0 (control), 3, 7,11,13 $\mathrm{kg} \mathrm{m}^{-2}$ Figure 5 .
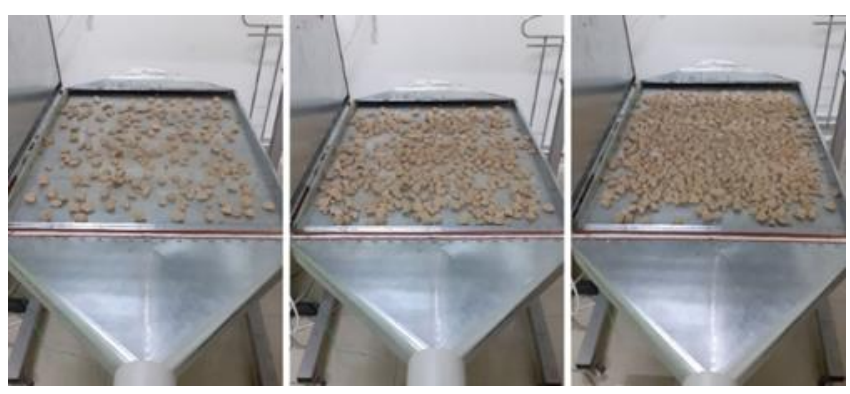

Figure 5. To used fire bricks fragments as a thermal energy storage. 
Voltage adjustment was made with dimmer switches for each of the 30 halogen lamps in the simulator. The irradiation intensity on the collector surface was adjusted to be homogeneously distributed and constant at $1000 \mathrm{~W} . \mathrm{m}^{-2}$.

The section of the air outlet of the collector is circular and has a diameter of $17 \mathrm{~cm}$. The amount of frequency to be applied to the radial fan was determined to be $1.0 \mathrm{~m} . \mathrm{s}^{-1}$ and the volumetric flow rate was calculated as $1.36 \mathrm{~m}^{3}$. $\mathrm{min}^{-1}$. The mass flow rate varies depending on the outlet air temperature. For this reason, the temperature-dependent specific mass of the air leaving the collector is calculated with Eq. 1 [6] and the mass flow is calculated with Eq. 2 [6] for each measured temperature.

$$
\begin{gathered}
\rho_{a}=M \frac{P}{R T} \\
\dot{m}_{a}=\rho_{a} V_{a}
\end{gathered}
$$

$\rho_{a}:$ Spesific mass, $\left(\mathrm{kg} \cdot \mathrm{m}^{-3}\right)$

$M$ : Molar mass of air, (28.97 ${\left.\mathrm{kg} . \mathrm{kmol}^{-1}\right)}^{-1}$

$P$ : Sea level standard atmospheric pressure, $(101.325 \mathrm{kPa})$

$R$ : Universal gas constant (8314.3 J. $\mathrm{kmol}^{-1} \cdot \mathrm{K}^{-1}$ )

$T$ : Air temperature, $(K)$

$\dot{m}_{a}$ : Air mass flow rate, $\left(\mathrm{kg} \cdot \mathrm{s}^{-1}\right)$

$V_{a}:$ Air velocity $\left(\mathrm{m}^{3} \cdot \mathrm{s}^{-1}\right)$.

Collector and parameters specific mass flow rate value $(G)$ used in the experiments were calculated with Eq. 3 [6] and the specific mass flow rate value for the experiments was found to be $125 \mathrm{~kg} \cdot \mathrm{h}^{-1} \cdot \mathrm{m}^{-2}$.

$$
G=\frac{\dot{m}_{a}}{A_{a}} 3600
$$

$A_{a}:$ Absorber surface area $\left(m^{2}\right)$.
The energy charged to the air passing through the collector for one minute was calculated with Eq. 4 [6].

$$
Q=\dot{m}_{a} C_{p}\left(T_{\text {out }}-T_{\text {in }}\right)
$$

$Q$ : Gained energy by air, ( $k c a l)$

$C_{p}$ : Specific heat capacity of air, $\left(0.24 \mathrm{kcal} . \mathrm{kg}^{-1} \cdot{ }^{\circ} \mathrm{C}\right)$

$T_{\text {out }}$ : Output air temperature, $\left({ }^{\circ} \mathrm{C}\right)$

$T_{\text {in }}$ : Input air temperature $\left({ }^{\circ} \mathrm{C}\right)$.

The thermal efficiency of solar collectors varies according to the angle and amount of solar radiation. Thermal efficiency is the ratio of the energy loaded to the working fluid to the amount of radiation coming to the panel surface. Thermal efficiency was calculated with Eq. 5 [6].

$$
\eta=\frac{Q_{t}}{A_{a} \cdot I \cdot t}
$$

$Q_{t}$ : Total gained energy by air during experiment, $(W h)$

$I$ : Irradiance, $\left(W \cdot m^{-2}\right)$

$t$ : Experiment time, $(h)$

The experiments were carried out by under $1000 \mathrm{~W} \cdot \mathrm{m}^{-2}$ irradiance during 180 minute and allowing only air flow to cool for the following 90 minutes. This process was repeated by placing fire brick fragments of different densities in the collector and the obtained temperature data were evaluated. Empty collector experiment without fire brick fragments was used as control experiment.

\section{Result and Discussions}

The experiments were carried out by placing fire brick fragments in the heater at a density of $0,3,7,11,13 \mathrm{~kg} \cdot \mathrm{m}^{-2}$, respectively. It has been observed in all experiments that the outlet and inlet air temperatures continuously increase during the 3 hours under irradiation, and close the gap within next 1.5 hours. Figure 6.

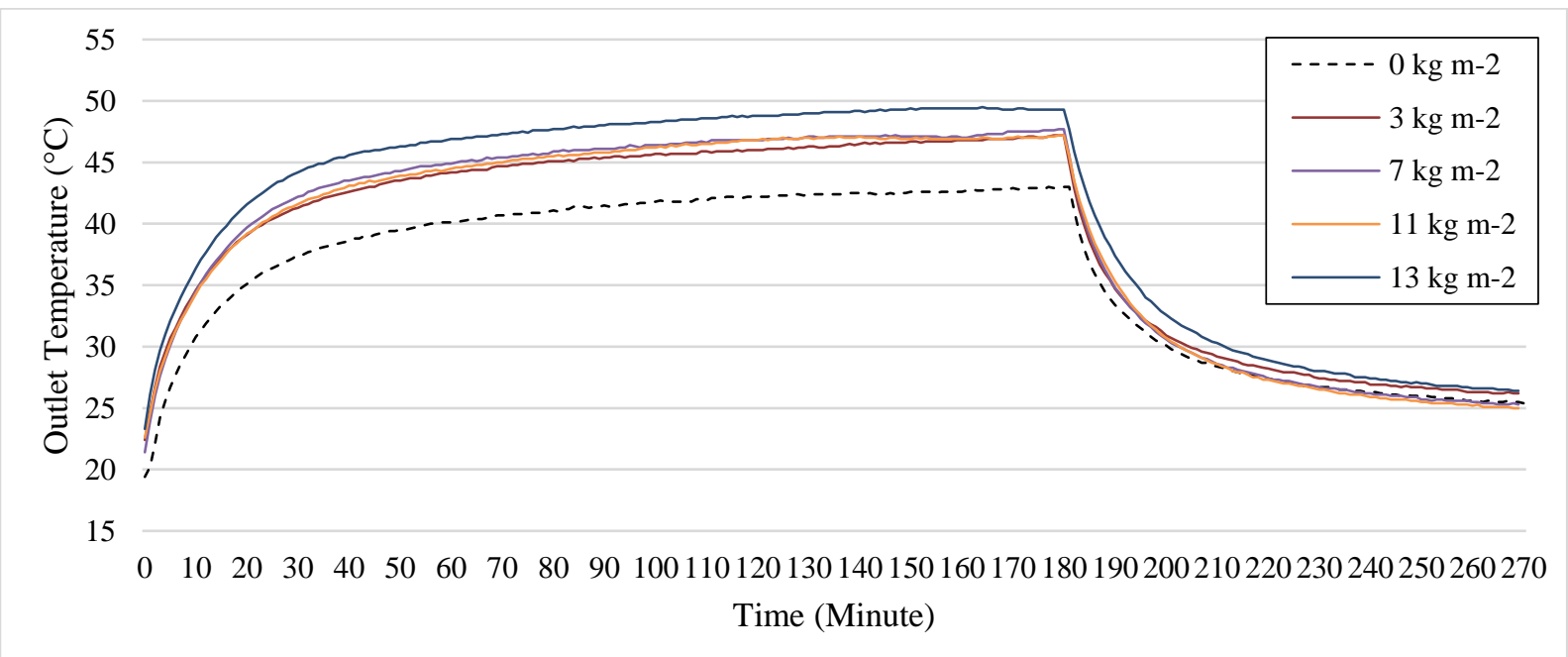

Figure $6.0,3,7,11$ and $13 \mathrm{~kg} \cdot \mathrm{m}^{-2}$ applied collector's outlet air temperature changes 
The graph of the change in the inlet and outlet air temperatures according to the different fire brick application densities is shown in Figure 7. For easier interpretation of the graph, the calculations of the areas under the curves of temperature differences are shown in Table 2.

Table 2. Comparison of areas under the curves in the temperature difference graph

\begin{tabular}{|c|c|c|}
\hline & $\begin{array}{c}\text { Irradiance Phase } \\
(0-180 \mathrm{~min})\end{array}$ & $\begin{array}{l}\text { Cooling Phase } \\
\text { (181-270 min) }\end{array}$ \\
\hline $0 \mathrm{~kg} \mathrm{~m}^{-2}\left(\Delta T^{*} t\right)$ & 2313.30 & 128.45 \\
\hline $3 \mathrm{~kg} \mathrm{~m}^{-2}\left(\Delta T^{*} t\right)$ & 2846.95 & 132.70 \\
\hline $7 \mathrm{~kg} \mathrm{~m}^{-2}\left(\Delta T^{*} t\right)$ & 3146.00 & 169.40 \\
\hline $11 \mathrm{~kg} \mathrm{~m}^{-2}\left(\Delta T^{*} t\right)$ & 3191.90 & 191.70 \\
\hline $13 \mathrm{~kg} \mathrm{~m}^{-2}\left(\Delta T^{*} t\right)$ & 3281.65 & 203.75 \\
\hline
\end{tabular}

The differences in collector efficiency of the applications are shown in Figure 8. Efficiency calculations were compared separately for the first 3 hours (under irradiation) and all 4.5 hours.

Using less storage material causes an increase in the gap inside the collector. As mentioned in the study of Aboul-Enein et al., it is seen that increasing the gap decreasing the outlet air temperature also in this study [30]. The use of thermal storage materials in solar collector is known to increase thermal efficiency and output air temperature [31]. The effect of the heat exchange observed during the cooling phase increased with the density of applied storage material. The effect value of the discharged energy per unit weight $(\mathrm{kg})$ of the applied fire bricks density was highest in $7 \mathrm{~kg} \mathrm{~m}^{-2}$ application and it was calculated as $2.03 \mathrm{Wh} \mathrm{kg}^{-1} \mathrm{~m}^{2}$. When this calculation was made for 3,11 and $13 \mathrm{~kg} \mathrm{~m}^{-2}$ applications, it was found to be $0.56,1.98$ and $1.95 \mathrm{Wh} \mathrm{kg}^{-1} \mathrm{~m}^{2}$ respectively. It is thought that this value does not increase gradually because of the change of path of the fluid air and the decrease of the contact surface of the air with the storage material.

In this study, the effect of thermal storage material used per unit area on thermal efficiency has been observed. It is seen that the thermal efficiency increases with the increase of the material used. Collector total efficiencies were 42.14, 51.23, 56.52, 57.42, $58.62 \%$ corresponding values to application densities $0,3,7,11,13 \mathrm{~kg} \mathrm{~m}^{-2}$ and efficiencies of under irradiance were $39.41,48.41,52.98,53.44,54.43 \%$ respectively.

Solar air heaters integrated with cylindirical copper tubes carrying low cost thermal energy storage materials as granular carbon powder, paraffin wax and combination of these were evaluated. Results showed that, the thermal efficiency reached to $78.3 \%$ by combination of storage materials and exhaust temperature of $50{ }^{\circ} \mathrm{C}$ [32]. Using synthetic oil in the black painted copper tubes of $\mathrm{SAH}$ as a sensible heat storage medium reached to the maximum efficiency of $67.7 \%$ at mass flow rate of $0.028 \mathrm{~kg} \mathrm{~s}^{-1}$ higher than the conventional SAH [11]. In another study, thermal efficiencies of $\mathrm{SAH}$ with storage were ranged between $68.4-71.9 \%$ and $2-3 \mathrm{~h}$ more effective than conventional SAHs [33]. It was varied between $12 \%$ and $65 \%$ per day and the maximum air temperature is higher than the temperature recorded without storage [34]. The SAHs with packed bed storage medium is more efficient than without storage interms of energy efficiency between $20.35 \%$ and $50.92 \%$. It is also capable to deliver the hot air in the range of 45 to $60{ }^{\circ} \mathrm{C}$ for a longer period. It could be possible to extend operation time up to $4 \mathrm{~h}$ with the temperature difference of 6-8 ${ }^{\circ} \mathrm{C}$ higher than the ambient temperature [35]. Using paraffin wax as pcm improved heat transfer and thermal efficiency reached to $39 \%$ for flat plate absorber plate and $43 \%$ for inclined absorber plate with PCM, while it was $31 \%$ for conventional SAH [36]. The thermal efficiencies of double glazed passive SAHs were investigated for different PCMs such as paraffin wax and palm oil and resulted with $38.4 \%$ and $41.0 \%$, respectively [37]. In another double pass SAH using paraffin wax reached the maximum thermal efficiency of $97 \%$ and provided benefical heat for $2.5 \mathrm{~h}$ after the sunset [38, 39]. Usage of powdered cherry stone and stone for sensible thermal energy storage in SAH resulted in average thermal efficiency between $6.05 \%$ and $39.99 \%$ depending on the air flow rate. Daily thermal efficiency with powdered cherry stone was found as $18.7 \%$ higher than SAH without heat storage. Powdered cherry stone and stone heat storage improved the energy generation for about 4 and 5 hours after sunset, respectively [40]. SAHs using paraffin wax and pure cement increased the heating period after 6.30 p.m. about 4 $\mathrm{h}$ and $2 \mathrm{~h}$, respectively [41].

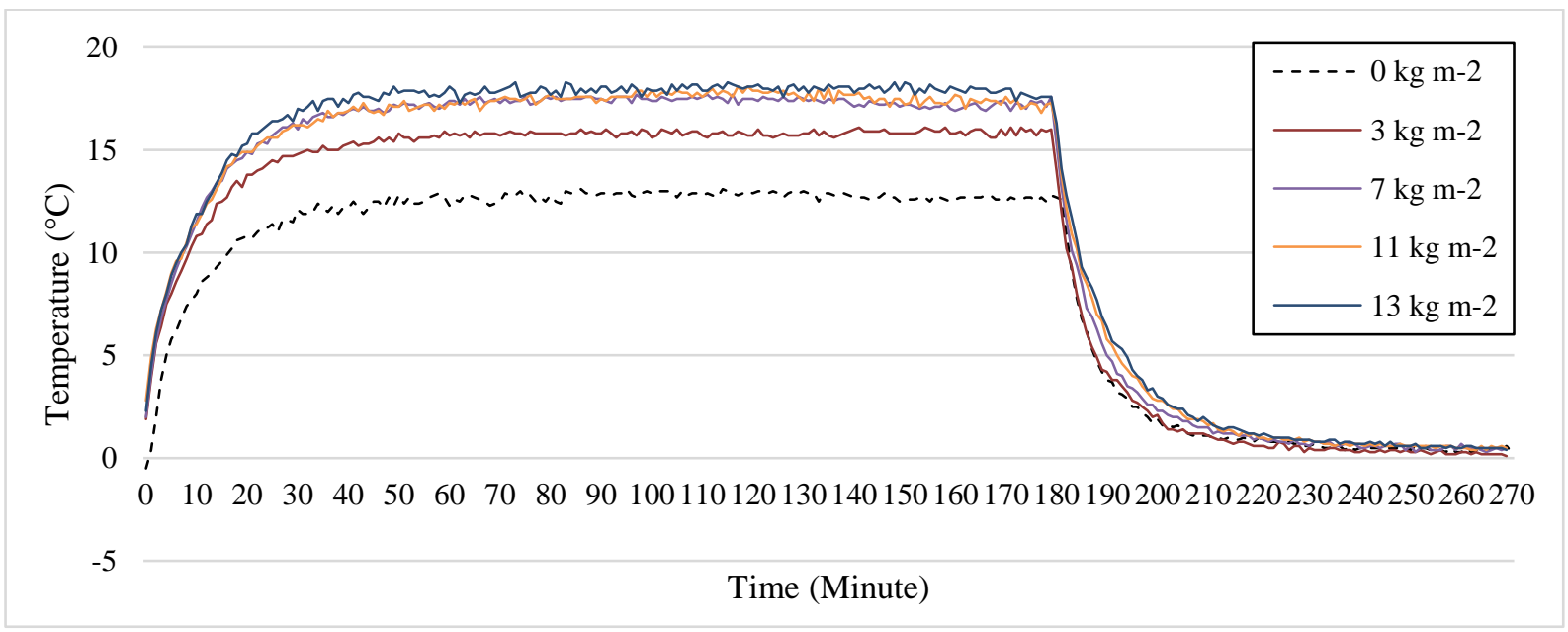

Figure 7. Time-dependent differences between inlet and outlet air temperatures. 


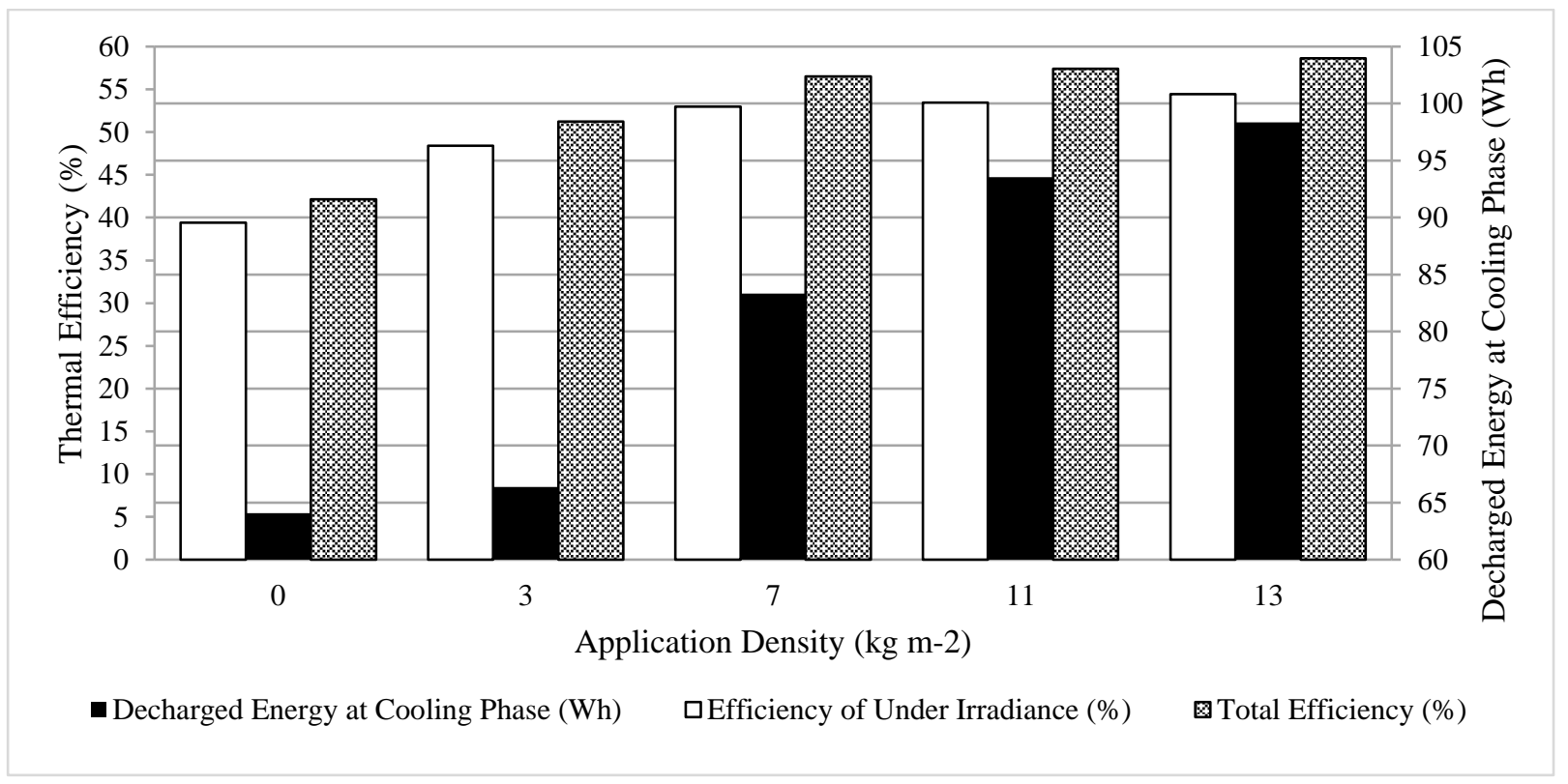

Figure 8. Effect of different density applications on thermal efficiency and stored energy amount.

\section{Conclusions}

The results obtained from the experiments showed that collector efficiency and outlet air temperature increased with applied fire brick fragments density. However, it has been observed that the amount of energy stored per unit of storage material does not increase continuously in a storage system integrated to the collector. This study shows that fire brick fragments can be used as a thermal energy storage material to provide hot air between 45 and $50{ }^{\circ} \mathrm{C}$, which is needed for drying or heating a certain volume.

\section{References}

[1]. S. A. Kalogirou, "Solar thermal collectors and applications", Progress in Energy and Combustion Science, vol. 30, pp. 231-295, 2004.

[2]. A. L. Bonnette and Xenophon, Memorabilia, Cornell University Press, 2014.

[3]. Evangelisti, L., Vollaro, R.D.L., Asdrubali, F., 2019. Latest advances on solar thermalcollectors: a comprehensive review. Renew. Sustain. Energy Rev. 114, 109318.

[4]. K. B. Varınca and M. T. Gönüllü, “Türkiye'de Güneş Enerjisi Potansiyeli ve Bu Potansiyelin Kullanım Derecesi, Yöntemi ve Yaygınlığı Üzerine Bir Araştırma", I. Ulusal Güneş ve Hidrojen Enerjisi Kongresi UGHEK 2006, ESOGÜ, Eskişehir, 270-275, (2006).

[5]. A. Kumar, R. P. Saini and J. S. Saini, "A review of thermohydraulic performance of artificially roughened solar air heaters", Renewable and Sustainable Energy Reviews, vol. 37, pp. 100-122, 2014.

[6]. A. Ghiami and S. Ghiami, "Comparative study based on energy and exergy analyses of a baffled solar air heater with latent storage collector", Applied Thermal Engineering, vol. 133, pp. 797-808, 2018.
[7]. M. K. Selçuk, "Solar Air Heaters and Their Applications", Solar Energy Engineering, Chapter 8, pp. 155-182, 1977.

[8]. P. S. Bhambare and G. V. Parishwad, "Study of Medium Temperature Solar Thermal Applications", International Journal of Applied Research and Studies, vol. 2, no 5, pp. 1 $11,2013$.

[9]. Haldorai S, Gurusamy S, Pradhapraj M. A review on thermal energy storage systems in solar air heaters. Int. J Energy Res. 2019, 43:6061-6077.

[10]. Javadi F.S., Metselaar H.S.C., Ganesan P., 2020. Performance improvement of solar thermal systems integrated with phase change materials (PCM), A review. Solar Energy, 206, 330-352.

[11]. Kalairasi G., Velraj R., Van jeswaran M.N., Pardian N.G., 2020. Experimental analysis and comparison of flat plate solar air heater with and without integrated sensible heat storage. Renewable Energy, 150, 255-265.

[12]. Gautam A., Saini R.P., 2020. A review on sensible heat based packed bed solar thermal energy storage system for low temperature applications. Solar Energy, 207, 937-956.

[13]. T. Tanaka, T. Tani, S. Sawata, K. Sakuta and T. Horigome, "Fundamental studies on heat storage of solar energy”, Solar Energy, vol. 19, pp. 415-419, 1976.

[14]. C. Choudhury, P. M. Chauhan and H.P. Garg, "Economic Design of a Rock Bed Storage Device for Storing Solar Thermal Energy", Solar Energy, vol. 55, no 1, pp. 29-37, 1995.

[15]. I. Sarbu and C. Sebarchievici, "A Comprehensive Review of Thermal Energy Storage", Sustainability, vol. 10, no 1, p. 191, 2018.

[16]. A. Gil, M. Medrano, I. Martorell, A. Lazaro, P. Dolado, B. Zelba and L. F. Cabeza, "State of the art on high temperature thermal energy storage for power generation", Renewable and Sustainable Energy Reviews, vol. 14, pp. 31 55,2010 . 
[17]. J. Gasia, L. Miró and L. F. Cabeza, "Review on system and material requirements for high temperature thermal energy storage.", Renewable and Sustainable Energy Reviews, vol. 75, pp. 1320-1338, 2017.

[18]. J. Singh, R. Singh and B. Bhushan, "Thermo Hyraulic Performance of Solar Air Duct Having Triangular Protrusions as Roughness Geometry", Journal of Thermal Engineering, vol. 1, no 7, pp. 607-620, 2015.

[19]. S. A. Nagalkar, A. B. Kanase-Patil and N. A. Phadtare, "Heat Transfer Enhancement in Solar Air Heater having Multi-Arc Shape Artificial Roughness with gap", International Conference on Technologies for Sustainable Development ICTSD 2015, Mumbai, India, (2015).

[20]. Mehmet Şener, "Etkin Bir Havalı Güneş Kollektörünün Tasarımı ve Optimizasyonu", Yüksek Lisans Tezi, Hitit Üniversitesi Fen Bilimleri Enstitüsü, Çorum, 2013.

[21]. Kumru Güreşçi, "Isı Alıcıların Kanal Akışında Isı ve Akış Karakteristiklerinin Sayısal Olarak İncelenmesi”, Yüksek Lisans Tezi, Atatürk Üniversitesi Fen Bilimleri Enstitüsü, Erzurum, 2014.

[22]. Saravanakumar, P.T., Mayilsamy, K., Forced convection flat plate solar air heaters with and without thermal storage. Journal of Scientific \& Industrial Research, Vol. 69, pp. 966968, 2010.

[23]. Natarajan, K., Thokchom, S.S., Verma, T.N., Nashine, P., Convective solar drying of Vitis vinifera \& Momordica charantia using thermal storage materials. Renewable Energy, Vol. 113, pp. 1193-1200, 2017.

[24]. Singh, T.S., Verma, T.N., Jahiya, M., Singh, P.K., Kheiruddin, M., Ajitkumar, K., Singh, N.W., Singh, H.D., Forced Convective Solar Air Heater: Effect of Thermal Storage Materials. International Journal of Applied Engineering Research, 13(8), pp.5877-5880, 2018.

[25]. Devlet Planlama Teşkilatı, Sekizinci Beş Yıllık Kalkınma Planı, “Taş ve Toprağa Dayalı Ürünlerin Sanayii Özel İhtisas Komisyonu Raporu (Refrakter), Ankara, 2001.

[26]. Yuansheng Pei, "Design of an LED-Based Solar Simulator", Honour thesis, Murdoch University, Perth, Western Australia, 2017.

[27]. A. M. Bazzi, Z. Klein, M. Sweeney, K. P. Kroger, P. S. Shenoy and P. T. Krein, "Solid-State Solar Simulator", IEEE Transactions on Industry Applications, vol. 48, no 4, pp. 1195-1202, 2012.

[28]. R. V. Parupudi, H. Singh and M. Kolokotroni, "Sun Simulator for Indoor Performance assessment of Solar Photovoltaic Cells", Energy Procedia, vol. 161, pp. 376-384, 2019.

[29]. Salih SM, Jalil JM, Najim SE. Experimental and numerical analysis of double-passsolar air heater utilizing multiple capsules PCM. Renewable Energy 2019; 143:105366

[30]. Aboul-Enein, S., El-Sebaii, A.A., Ramadan, M.R.I, ElGohary, H.G., Parametric study of a solar air heater with and without thermal storage for solar drying applications. Renewable Energy, 21, pp.505-522, 2000.
[31]. Krishnananth, S.S., and Murugavel, K.K., Experimental study on double pass solar air heater with thermal energy storage. Journal of King Saud University - Engineering Sciences, 25, pp.135-140, 2013.

[32]. Saxena A., Verma P., Srivastava G., Kishore N. Design and thermal performance evaluation of an air heater with low cost thermal energy storage. Applied Thermal engineering, $167,114768$.

[33]. Sajawal M., Rahman T., Ali H.M., Sajjad U., Raza A., Bhatti M.S., 2019. Experimental thermal performance analysis of finned tube phase change material based double pass solar air heater. Case Studies in Thermal Engineering, $15,100543$.

[34]. Sunilraj B.A., Esmaramoorthy M., 2020. Experimental study on hybrid natural circulation type solar air heater with paraffin wax based thermal storage. Material Today: Proceeding 23, 49-52.

[35]. Vijayan S., Arjunan T.V., Kumar A., Mortheswaran M.M., "Experimental and thermal performance investigations on sensible storage based solar air heater" Journal of Energy Storage, 31, 101620.

[36]. Sudhakar P, Cheralathan M. Thermal performance enhancement of solar air collector using a novel V-groove absorber plate with pin-fins for drying agricultural products: an experimental study. J Therm Anal Calorim 2020;140: 2397-408. https://doi.org/10.1007/s10973-019-08952-9.

[37]. O. Ojike, W.I. Okonkwo, Study of a passive solar air heater using palm oil and paraffin as storage media, Case Stud. Therm. $\quad$ Eng. 14 (2019), https://doi.org/10.1016/j.csite.2019.100454.

[38]. W. Baig, H.M. Ali, An experimental investigation of performance of a double pass solar air heater with foam aluminum thermal storage medium, Case Studies in Thermal Engineering 14 (2019) 100440

[39]. Bubnovich V, Reyes A, Díaz M. Computational simulation of the thermal performance of a solar air heater integrated with a phase change. Material. J Sol Energy Eng 2019;141(5):051011. https://doi.org/10.1115/1.4043549.

[40]. Abuşka M., Şevik S., Kayapunar A. Comparative energy and exergy performance investigation of forced convection solar air collectors with cherry stone/powder. Renew Energy 2019; 143: 34-46. https://doi.org/10.1016/j.renene.2019.04.149.

[41]. A.R. Abdulmunem, A.H. Abed, H.A. Hussien, P.M. Samin, H.A. Rahman, Improving the performance of solar air heater using high thermal storagematerials, Ann. Chimie Sci. Materiaux 43 389e394,https://doi.org/10.18280/acsm.430605.
(2019) 